\title{
PROFIL TNF- $\alpha$ SESUDAH SENAM LANSIA PADA LANSIA DI PANTI WREDHA BETHANIA LEMBEAN KOTA MANADO
}

\author{
${ }^{1}$ Michael Tulong \\ ${ }^{2}$ Siantan Supit \\ ${ }^{2}$ Joice N. A. Engka \\ ${ }^{1}$ Kandidat Skripsi Fakultas Kedokteran Universitas Sam Ratulangi Manado \\ ${ }^{2}$ Bagian Fisiologi Kedokteran Universitas Sam Ratulangi Manado \\ Email: mtulong11_016@ymail.com
}

\begin{abstract}
Tumor Necrosis Factor- $\alpha$ (TNF- $\alpha$ ) is a systemic pro-inflammatory cytokine which is responsible to a trauma, injury, or inflammation in human body. Physical activity can physiologically affect the human body, inter alia the immune system. This was an experimental study with a post test design. This study aimed to determine the profile of TNF- $\alpha$ after doing gymnastics among the elderly at nursing home Bethania Lembean. Samples included 30 peoples who met the inclusion criteria, i.e. over 64 years old, followed the gymnastics for 5 weeks regularly, approbated as respondents, healthy, and signed the informed consent. The TNF- $\alpha$ concentration measurements were done by using enzyme-linked immunosorbent assay (ELISA) Quantikine ${ }^{\circledR}$ Human TNF- $\alpha$. The results showed that the average conventration of TNF- $\alpha$ after elderly gymnastics was $70.54 \mathrm{pg} / \mathrm{ml}$, with the highest value of $88.90 \mathrm{pg} / \mathrm{mL}$ and the lowest value of 12.54 $\mathrm{pg} / \mathrm{mL}$. For all respondents, TNF- $\alpha$ was within normal limit and ranged between 10-100 pg / mL. Conclusion: In this study, TNF- $\alpha$ concentrations after elderly gymnastics for 5 weeks were within normal limits
\end{abstract}

Keywords: TNF- $\alpha$, elderly gymnastics

\begin{abstract}
Abstrak: Tumor Necrosis Factor- $\alpha$ (TNF- $\alpha$ ) merupakan suatu sitokin sistemik pro-inflamasi, yang berespons terhadap suatu cedera trauma atau peradangan yang terjadi dalam tubuh manusia. Kegiatan fisik dapat berdampak cukup besar pada tubuh manusia, dimana dapat merubah sistem imun tubuh secara fisiologis. Penelitian ini bersifat eksperimental dengan rancangan post test design dan bertujuan untuk mengetahui profil TNF- $\alpha$ sesudah senam lansia di Panti Wredha Bethania Lembean. Sampel penelitian berjumlah 30 orang yang memenuhi kriteria inklusi yaitu berumur di atas 64 tahun, teratur mengikuti senam lansia selama 5 minggu, bersedia menjadi responden, sehat saat di periksa, dan menandatangani informed consent. Pengukuran konsentrasi TNF- $\alpha$ di lakukan dengan menggunakan enzyme-linked immunosorbent assay (ELISA) Quantikine (BHuman TNF- $\alpha$. Hasil penelitian memperlihatkan bahwa rerata kadar TNF- $\alpha$ sesudah senam lansia 70,54 pg/ml, dengan nilai tertinggi 88,90 pg/mL dan nilai terendah $12,54 \mathrm{pg} / \mathrm{mL}$. Berdasarkan hasil yang di dapat, semua kadar TNF- $\alpha$ masih dalam batas normal dengan nilai 10-100 pg/mL. Simpulan: TNF- $\alpha$ sesudah senam lansia selama 5 minggu masih dalam batas normal.
\end{abstract}

Kata kunci:TNF- $\alpha$, senam lansia

Kurangnya kegiatan fisik secara rutin dapat membuat tubuh mengalami penurunan kesehatan. Berbagai faktor seperti usia, perilaku hidup dan penyakit juga dapat menambah risiko kesehatan pada tubuh kita. Oleh sebab itu kita harus meminimalisasi risiko gangguan kesehatan.

Kesehatan tubuh dapat dijaga dengan melakukan kegiatan yang berguna untuk mengurangi risiko turunnya kesehatan, salah satunya adalah dengan melakukan kegiatan senam. Senam merupakan suatu 
aktifitas fisik yang melibatkan suatu gerakan kompleks yang dilakukan seiring dengan irama yang di bawakan. Senam banyak digunakan di kalangan umum sebagai olahraga sederhana yang tidak memerlukan alat bantu yang kompleks dalam melakukan latihan tersebut.

Senam dapat memberikan dampak positif dan negatif bagi yang melakukannya. Dengan melakukan senam dalam intensitas yang normal, dapat meningkatkan ketahanan tubuh dan juga kebugaran tubuh. Jika dilakukan dengan intensitas yang berlebihan, hal tersebut dapat menyebabkan gangguan pada kesehatan tubuh kita ${ }^{1}$. Suatu kegiatan olahraga juga harus disesuaikan dengan usia seseorang yang akan melakukannya.

Perbedaan umur dapat memengaruhi suatu intensitas olahraga yang dapat dilakukan. Hal tersebut dilihat dari kemampuan seseorang secara fisiologis akan menurun seiring usia bertambah. Kegiatan senam memiliki banyak jenis yang dapat di sesuaikan berdasarkan intensitas yang bisa dilakukan seseorang. Pada saat ini diperkirakan umur harapan hidup di Manado adalah 72,96 tahun, umur tersebut lebih tinggi dari angka harapan hidup Sulawesi Utara yaitu 72,62 tahun. Hal tersebut membuat Manado menjadi salah satu wilayah yang memiliki angka harapan hidup bagi lansia tertinggi di Sulawesi Utara ${ }^{2}$. Pada orang sudah tua (lansia), suatu kegiatan olahraga yang sederhana saja dapat menjadi kegiatan yang cukup berat untuk para lansia. Oleh sebab itu harus mengetahui intensitas yang diberikan pada lansia. Jika memberikan suatu latihan yang memiliki intensitas tinggi maka akan berdampak bagi keadaan tubuh.

Suatu kegiatan olahraga dapat memengaruhi respon imunologik dan perubahan homeostasis pada seseorang. Jika satu atau lebih sistem kekebalan tubuh gagal berfungsi, akan berdampak pada sel. Suatu olahraga yang dilakukan dengan intensitas yang tinggi dapat memicu organ tubuh menjadi stres dan cidera, dan membuat perubahan pada sitokin yang ada di dalam tubuh. Dari berbagai sitokin yang berubah, salah satunya ialah TNF- $\alpha$ (Tumor Necrosis Factor- $\alpha)^{3}$.

TNF- $\alpha$ dahulu dikenal dengan berbagai nama, yaitu cachetin, necrosin, macrofag sitotoksin, atau faktor sitotoksik. Bersama dengan IFN- $\gamma$, TNF- $\alpha$ bersifat sitotoksik bagi berbagai sel tumor. TNF- $\alpha$ juga terbukti merupakan modulator respon imun yang kuat dalam menginduksi molekul adhesi, sitokin lain dan aktifasi neutrofil. TNF yang diproduksi dalam jangka panjang/ kronik, dapat menimbulkan tissue remodeling. ${ }^{4}$ Selain itu, TNF dapat berfungsi sebagai faktor angiogenesis dengan membentuk pembuluh darah baru, serta dapat berfungsi sebagai faktor pertumbuhan fibroblas, yang mengakibatkan pembentukan jaringan ikat. Jika produksi TNF tetap berlanjut jaringanjaringan tersebut dapat merupakan jaringan limfoid baru tempat berkumpulnya sel limfosit B dan T. TNF- $\alpha$ merupakan sitokin sistemik yang disekresi oleh makrofag, terlibat dalam peradangan dan merupakan anggota dari kelompok sitokin yang merangsang respon fase akut terhadap bakteri gram-negatif dan mikroba lainnya, serta pada cedera trauma. Sumber utama TNF- $\alpha$ adalah fagosit monokuler dan sel T yang diaktifkan antigen, sel NK (Natural Killer) dan sel mast.

Penelitian ini bertujuan untuk mengetahui profil TNF- $\alpha$ sesudah melakukan latihan senam lansia di Panti Wredha Bethania Lembean.

\section{METODE PENELITIAN}

Penelitian ini bersifat eksperimental dengan rancangan post test design. Populasi penelitian ialah semua lansia di Panti Wredha Bethania Lembean. Sampel diambil dengan kriteria inklusi, yaitu: umur $\geq 64$ tahun berdasarkan batas umur terendah lansia oleh WHO; teratur mengikuti senam lansia selama $\geq 1$ bulan; bersedia menjadi responden; sehat saat diperiksa; dan menandatangani informed consent. Penelitian dilakukan selama bulan Oktober 2014 sampai Januari 2015.

Data yang telah didapatkan, dikumpul- 
kan dan diolah untuk mendapatkan kadar TNF- $\alpha$ pada lansiadi Panti Wredha Bethania Lembean sesudah melakukan senam lansia. Data diolah secara manual dan komputerisasi serta disajikan dalam bentukpersentase, rerata dan frekuensi.

\section{HASIL PENELITIAN}

Penelitian ini dilaksanakan pada bulan Oktober 2014 sampai bulan Januari 2015. Lokasi bertempat di Panti Wredha Bethania Lembean. Responden penelitian ini adalah para lansia di Panti Wredha Bethania Lembean yang telah memenuhi kriteria inklusi dan bersedia untuk diteliti yang berjumlah 30 orang.

\section{Distribusi Karakteristik Responden Penelitian Berdasarkan Jenis Kelamin}

Tabel 1. Distribusi karakteristik responden penelitian berdasarkan jenis kelamin

\begin{tabular}{ccc}
\hline Jenis Kelamin & $\mathrm{n}$ & $\%$ \\
\hline Laki-laki & 11 & 36,67 \\
Perempuan & 19 & 63,33 \\
Jumlah & 30 & 100,0 \\
\hline
\end{tabular}

Tabel 1 menunjukkan sebagian besar responden dalam penelitian berjenis kelamin perempuan yakni sebanyak 19 responden (63,33\%). Responden dengan jenis kelamin laki-laki hanya berjumlah 11 responden (36,67\%).

\section{Distribusi Karakteristik Responden Penelitian Berdasarkan Umur}

Tabel 2. Distribusi karakteristik responden penelitian berdasarkan umur

\begin{tabular}{ccc}
\hline Umur & $\mathrm{n}$ & $\%$ \\
\hline (64-74 Tahun) & 22 & 73,34 \\
(75-90 Tahun) & 7 & 23,33 \\
(>90 Tahun) & 1 & 3,33 \\
Jumlah & 30 & 100,0 \\
\hline
\end{tabular}

Tabel 2 menunjukkan bahwa kelompok terbesar responden terdapat pada umur antara 64-74 tahun yaitu sebanyak 22 responden (73,34\%), umur 75-90 tahun sebanyak 7 responden (23,33\%) dan paling sedikit adalah umur $>90$ tahun yaitu sebanyak 1 responden (3,33\%).

\section{Distribusi Nilai Rerata TNF- $\alpha$ Responden Penelitian Berdasarkan Jenis Kelamin}

Tabel 3. Distribusi nilai rerata TNF- $\alpha$ berdasarkan jenis kelamin

\begin{tabular}{cccc}
\hline $\begin{array}{c}\text { Jenis } \\
\text { Kelamin }\end{array}$ & $\mathrm{n}$ & $\%$ & $\begin{array}{c}\text { RerataTNF- } \alpha \\
\text { pg/ml }\end{array}$ \\
\hline Laki-laki & 11 & 36,67 & 77,41 \\
Perempuan & 19 & 63,33 & 66,64 \\
Jumlah & 30 & 100 & 70,59 \\
\hline
\end{tabular}

Tabel 3 menunjukkan bahwa kelompok responden laki-laki memiliki nilai rerata TNF- $\alpha$ tertinggi yakni 77,41 $\mathrm{pg} / \mathrm{ml}$ dari sebanyak 11 responden (36,67\%) dan untuk kelompok perempuan memiliki nilai rerata TNF- $\alpha$ sebesar 66,64 $\mathrm{pg} / \mathrm{ml}$ dari 19 responden (66,64\%). Sedangkan nilai rerata TNF- $\alpha$ dari seluruh responden yang adalah $70,59 \mathrm{pg} / \mathrm{ml}$.

\section{Distribusi Nilai Rerata TNF- $\alpha$ Responden Penelitian Berdasarkan Kelompok Umur}

Tabel 4. Distribusi nilairerataTNF- $\alpha$ responden penelitian berdasarkan kelompok umur

\begin{tabular}{cccc}
\hline $\begin{array}{c}\text { Umur } \\
\text { (Tahun) }\end{array}$ & $\mathrm{n}$ & $\%$ & $\begin{array}{c}\text { RerataTNF- } \alpha \\
\text { pg/ml }\end{array}$ \\
\hline$(64-74)$ & 22 & 73,34 & 70,92 \\
$(75-90)$ & 7 & 23,33 & 70,10 \\
$(>90)$ & 1 & 3,33 & 66,92 \\
Jumlah & 30 & 100 & 70,59 \\
\hline
\end{tabular}

Tabel 4 menunjukkan bahwa responden berusia 64-74 tahun yaitu sebanyak 22 responden (73,34\%) memiliki nilai rerata TNF- $\alpha$ sebesar $70,92 \mathrm{pg} / \mathrm{ml}$, responden berusia 75-90 tahun yang 
Tulong, Supit, Engka: Profil TNF- $\alpha$ sesudah senam lansia...

berjumlah 7 responden (23,33\%)memiliki nilai rerata TNF- $\alpha$ sebesar $70,10 \mathrm{pg} / \mathrm{ml}$ dan responden yang berusia $>90$ tahun $(3,33 \%)$ memiliki nilai rerata $\mathrm{TNF}-\alpha$ sebesar 66,92 pg/ml.

\section{Distribusi Karakteristik Responden Penelitian Berdasarkan Range NilaiTNF-a}

Tabel 5. Distribusi jumlah responden berdasarkan range nilai TNF- $\alpha$

\begin{tabular}{cccc}
\hline TNF- $\alpha \mathrm{pg} / \mathrm{ml}$ & $\mathrm{n}$ & $\%$ & $\begin{array}{c}\text { RerataTNF- } \alpha \\
\mathrm{pg} / \mathrm{ml}\end{array}$ \\
\hline$<10 \mathrm{pg} / \mathrm{ml}$ & 0 & 0 & 0 \\
$10-100 \mathrm{pg} / \mathrm{ml}$ & 30 & 100 & 70,59 \\
$>100 \mathrm{pg} / \mathrm{ml}$ & 0 & 0 & 0 \\
\hline
\end{tabular}

Tabel 5 menunjukkan bahwa seluruh responden berada pada range nilai TNF- $\alpha$ $10-100 \mathrm{pg} / \mathrm{ml}$, dan tidak terdapat responden pada range $<10 \mathrm{pg} / \mathrm{ml}$ dan range $>100$ $\mathrm{pg} / \mathrm{ml}$. TNF- $\alpha$ 10-100 pg/ml merupakan range normal, dimana pada range tersebut memberikan gambaran normal TNF- $\alpha$ dan memberikan respon imunitas seluler yang baik terhadap infeksi akut dan berperan sebagai imunitas seluler lokal.

\section{Deskripsi statistik TNF- $\alpha$ sesudah senam lansia di panti wredha Bethania Lembean}

Tabel 6. Deskripsi statistik TNF- $\alpha$ sesudah senam lansia

n Min Max Mean Std. Dev

$\begin{array}{rrrr}\text { Post Lab } 30 & 12,54 \quad 88,90 \quad 70,59 & 15,35 \\ \text { TNF- } \alpha & & & \end{array}$

Tabel 6 menunjukkan bahwa dari keseluruhan jumlah sampel yaitu sebanyak 30 sampel, memiliki nilai minimum TNF$\alpha$ sebesar $12,54 \mathrm{pg} / \mathrm{ml}$, nilai maksimum TNF- $\alpha$ sebesar $88,90 \mathrm{pg} / \mathrm{ml}$, dan memiliki rata-rata nilai TNF- $\alpha$ sebesar $70,59 \mathrm{pg} / \mathrm{ml}$ dengan standar deviasi 15,35.

\section{BAHASAN}

Hasil penelitian dari 30 responden lansiadi Panti Wredha Bethania Lembean, sebanyak 11 sampel berjenis kelamin lakilaki dengan persentase sebanyak 36,67 \% dan memiliki rerata TNF- $\alpha$ sebesar 77,41 $\mathrm{pg} / \mathrm{mL}$ dan 19 sampel berjenis kelamin perempuan dengan persentasi sebanyak $63,33 \%$ dan memiliki rerata TNF- $\alpha$ sebesar 66,64 pg/mL. Pada penelitian ini jenis kelamin perempuan lebih banyak dibanding jenis kelamin laki-laki namun dalam hal nilai rata-rata, jenis kelamin laki-laki memiliki nilai TNF- $\alpha$ lebih tinggi dari wanita. Setelah menggolongkan ke 30 responden tersebut berdasarkan umur, dalam penelitian ini ditemukan bahwa lansia yang berumur 64-74 tahun memiliki jumlah sebanyak 22 responden (73,34\%) dan memiliki rerata kadar TNF- $\alpha$ sebesar $70,92 \mathrm{pg} / \mathrm{mL}$. Untuk yang berumur 75-90 tahun memiliki jumlah responden sebanyak 7 orang (23,33\%) dan memiliki rerata kadar TNF- $\alpha$ sebesar 70,10 pg/mL. Pada umur di atas 90 tahun memiliki jumlah responden sebanyak 1 orang $(3,33 \%)$ memiliki rerata kadar TNF- $\alpha$ sebesar 66,92 pg/mL. Lansia pada umur 64-74 merupakan golongan lansia terbanyak pada penelitian. Dari perbandingan ke tiga golongan umur tersebut dapat disimpulkan bahwa belum tentu umur yang bertambah akan meningkatkan kadar TNF- $\alpha$, pada hasil tersebut membuktikan bahwa ketika umur bertambah maka rata-rata kadar TNF- $\alpha$ cenderung menurun (Tabel 4).

Kadar TNF- $\alpha$ tidak bisa dilihat dari faktor umur saja, tidak mutlak suatu kadar TNF- $\alpha$ pada lansia yang lebih dewasa memiliki kadar TNF- $\alpha$ yang lebih tinggi. Berbagai faktor lainnya seperti indeks masa tubuh, psikologi, sebuah penyakit, dan intensitasnya suatu latihan dapat memicu naik atau turunnya suatu TNF- $\alpha{ }^{5,6}$ Kadar TNF- $\alpha$ dapat dibedakan menjadi 3 bagian, yaitu dengan nilai TNF- $\alpha<10 \mathrm{pg} / \mathrm{mL}$ atau dalam arti Kurang, dengan nilai TNF- $\alpha$ 10$100 \mathrm{pg} / \mathrm{mL}$ atau dalam arti Normal, dan dengan nilai TNF- $\alpha>100 \mathrm{pg} / \mathrm{mL}$ atau 
dalam arti lain Tinggi. Berdasarkan tabel 5, tidak ada responden pada nilai TNF- $\alpha<10$ $\mathrm{pg} / \mathrm{mL}$ dan pada nilai TNF- $\alpha>100 \mathrm{pg} / \mathrm{mL}$. Pada nilai TNF- $\alpha$ 10-100 pg/mL terdapat jumlah responden sebanyak 30 orang (100\%) dengan rerata kadar TNF- $\alpha$ sebesar $70,59 \mathrm{pg} / \mathrm{ml}$ dimana hasil tersebut masuk dalam range normal.

\section{SIMPULAN}

Kadar TNF- $\alpha$ sesudah senam lansia selama 5 minggu masih dalam batas normal.

\section{SARAN}

Disarankan untuk melakukan penelitian lebih lanjut tentang profil TNF$\alpha$ terhadap beberapa cabang senam lainnya. Selain itu diharapkan dapat menambah jumlah sampel lebih banyak dan dalam bidang senam yang lain agar dapat melihat lebih luas profil TNF- $\alpha$ terhadap kegiatan senam.

Disarankan juga bagi peneliti agar dapat memaksimalkan hasil yang di dapat yaitu dengan melakukan latihan sekurangkurangnya 8 minggu serta dilakukan dalam kondisi responden yang lebih prima dan dalam pengawasan instruktur yang sudah terlatih.

Untuk masyarakat agar dalam latihan senam, sebaiknya dilakukan dalam keadaan yang baik dan tanpa memaksakan diri. Hal tersebut di lakukan untuk menghindari dampak negative akibat dari aktifitas fisik maupun latihan fisik yang berlebihan.

\section{DAFTAR PUSTAKA}

1. Efek Samping Olahraga Berlebihan. http://doktersehat.com/efek-sampingolahraga-berlebihan/ (Diakses pada tanggal 17 September 2014).

2. Angka Harapan Hidup Sulawesi Utara. http://sulut.bps.go.id/linkTabelStatis/ view/id/15 (Diakses pada tanggal 20 September 2014).

3. Pedersen BK, Steensberg A, Fischer C, Keller C, Ostrowski K, and Schjerling P. Exercise and Cytokines With Particular Focus on MuscleDerived IL-6, 2001.

4. Han YP, Tuan TL, Wu H, Hughes M, Garner WL. TNF- $\alpha$ stimulates activation of pro-MMP2 in human skin through NF- $\kappa \mathrm{B}$ mediated induction of MT1-MMP .2000; p.2

5. Pencetus

$$
\text { TNF- } \alpha \text {. }
$$

http: //www.ncbi.nlm.nih.gov/pmc/articles/ PMC3307173/ (Diakses pada tanggal 25Januari 2015).

6. Fitri Y. Pengaruh Latihan Fisik (Senam Jantung Sehat) Terhadap Kadar TnfA Dan Kadar Gula Darah Pada Penderita Obesitas. 2014; p.2-3. 